\title{
Cultural Meaning of Monument Building in the Life of Toba Batak Tribe in Pangururan and Palipi Subdistricts, Samosir Regency
}

\author{
Corry $^{1}$, Ulung Napitu ${ }^{1}$, Supsiloani ${ }^{2}$, Resna Napitu ${ }^{3}$ \\ ${ }^{1}$ Faculty of Teacher Training and Education, Universitas Simalungun, Indonesia \\ ${ }^{2}$ Anthropology Study Program, Universitas Negeri Medan, Indonesia \\ ${ }^{3}$ Faculty of Economic, Universitas Simalungun, Indonesia \\ E-mail: purbacorry470@gmail.com
}

\begin{abstract}
:
This study aims to analyze the cultural meaning of monument building in the life of Toba Batak tribe in Pangururan and Palipi Subdistricts, Samosir Regency. This study uses descriptive qualitative methods that are relevant to the phenomenology methodology. The results of this study indicate that the general meaning of the monument building process contained in the lives of Batak Toba community in Samosir Regency can be categorized into two, namely the meaning of the monument buiding in terms of religion and culture. From the aspect of religion consists of (1) The Meaning of the Sacralization (2) The Meaning of the Position of Soul (3) The Meaning of the Blessing (4) The Meaning of Strengthening Alliance Bonds. From the aspect of monument building culture is considered a unifying bond between all descendants of the clan, and the ancestral spirits of clans, namely: (1) The Meaning of the Unifying Clans (2) The Meaning of the Conflict Resolution (3) The Meaning of the Raising Social Status. (4) The Meanings as Stamps for Regional Ownership (5) The Meanings of Clans Identity (6) The Meaning of Social Prestige Exhibition.
\end{abstract}

Keywords:

meaning; culture; monument; Batak tribe; Indonesia

\section{Introduction}

The tradition of the monument building of mangongkal holi and panangkok saringsaring is one of Toba Batak traditions with the aim of honoring the ancestors and spirits of parents. Through this series of events it is believed that hasangapon, hagabean and hamoraon will be obtained for each clan, clan group or hereditary group. The monument that was ready to be built (tambak na timbo and napir stone) in it was provided where the ancestral bones were placed first, while the youngest were the lowest placed in pairs (husband and wife) (Situngkir, 2011: 3).

Before the entry of the monotheistic religion into Batak land, already found ponds or buildings of grave stones (paromasan), sarcophagi, stone jars, stone tombs and stone carvings in Batak land. This is an indication that the tradition of burial of such bodies is the result of culture in the megalithic period which is estimated to be 3000 years BC. This tradition explains that life which originates from belief in ancestral spirits until now its influence is still felt in various regions, especially on the island of Samosir (Situngkir, 2011: 1-2).

Monument is a building of art that contains meaning to commemorate an event or to honor ancestors or hereditary groups. In Batak terms, a monument is often called a simin, and tambak batu napir made of ordinary buildings. While the tambak na timbo is called a high tomb building where the bones of the ancestors of one clan have been collected for generations (Marbun, 1987: 17). 
The strong roots of religion, cosmology and socio-cultural values strengthen the primordial ties in the life of Toba Batak people. The stone napir buildng, tambak na timbo and Mangongkal holi ceremony in addition to having religious and cultural significance also affect the cognition of Toba Batak tribe wherever they are. This phenomenon strengthens the bond of integration in clan ancestors, parent clans, clan branches and nuclear families. Toba Batak tribe is a unity in terms of carrying out traditional ceremonies both in the area of origin and those in the overseas area, because according to its cosmological value, the overseas area is an expansion of the area of origin (Bona Pasogit) (Siahaan (2003: 14).

To analyze the cultural meaning behind social reality that exists in depth, comprehensively and holistically in the life of modern Batak Toba people who have embraced religion today, as well as searching for religious roots, a research study with the title of this study aims to analyze the Cultural Phenomenon of Monument buiding in the Life of Toba Batak tribes in $\mathrm{f}$ Pangururan and Palipi Subdistricts, Samosir Regency..

\section{Review of Literatures}

\subsection{Theory of Semiotic: Symbols, Signs, and Construction of Meanings}

Society is a collection of people who live together for quite a long time. So it's not just a crowd or a crowd in a moment, like a crowd of terminals, markets or on a soccer field. In the long time together, social interaction occurred (Ismail, 2019). The term semiotic comes from the Greek word, semeion which means sign theory. Another opinion put forward by Hartoto (1984: 42) which states that semiotics is the way the work is interpreted by observers and the community through signs and symbols. Based on this, that semiotics as a science is studying the life of signs in a broad sense in society both straightforward and classy using language and non-language (Rusmana, 2014: 23). Semiotics is divided into nine types, namely:

a. Analytical semiotic is a semiotic that produces a sign system

b. Descriptive semiotics are semiotics that pay attention to the sign system that can be experienced by everyone, even though there is a sign since the past it remains as witnessed today.

c. Faunal semiotics are semitotics which have signs from animals when communicating between them by using certain signs that some of them can understand by some humans.

d. Cultural semiotics, namely semiotics specifically examines the sign system that applies in a particular society's culture.

e. Narrative semiotics are semiotics that examine the sign system in the narrative in the form of myths and oral stories.

f. Natural semiotics namely semiotics specifically examine the sign system produced by nature.

g. Semitic normative is semiotic which specifically examines the sign system created by humans and manifests the norms.

h. Social Semiotics is a semiotic that specifically examines the sign system produced by humans in the form of symbols and sentences.

i. Structural semiotics, namely semiotics that specifically examine the sign system that is manifested through the structure of language (Pateda, 2001: 29).

The things that need to be discussed in semiotics are as follows:

a. Signs are a reflection of symptoms that have a number of criteria such as name, role, function, purpose and meaning.

b. Symbols or symbols are things or conditions that guide the subject's understanding of the object. 
c. Icons are the relationship between signs and references in the form of similarity.

d. Index is interpreted by the relationship between signs and references that arise because of the closeness of existence.

e. Sign is a matter and condition given by subject to object through non-verbal language or non-verbal language (Rusmana, 2014: 39-45).

Semiotics is a form of development that underlies the formation of an understanding that refers to the formation of a meaning that can never be separated from the meaning, perception, or understanding of whatever we see. Scientific studies that examine symbols or signs and the construction of meaning contained in these signs are called Semiotics. Semiotic tradition consists of a set of theories about how signs represent objects, ideas, circumstances, situations, feelings and conditions outside the signs themselves (Littlejohn, 2009: 53).

According to Pane (2020) semiotics is related to the phenomenon of signs in all its abundance and variety: letters, pictures, texts,acoustics, road signs, verbal signs, movements, icons, symbols, allegories, logos, indexes, hieroglyphs, pictures, signs naturally, celestial signs and architectural objects among others.

Semiotic aims to find out the meanings contained in a sign or interpret meaning so that it is known how the community constructs the meanings contained in a symbol or symbol. This concept of meaning cannot be separated from certain ideological perspectives or values as well as cultural concepts which are the realm of the thinking of the people where the symbols were created. Cultural code which is one of the factors in the construction of meaning in a symbol becomes an important aspect to determine the message construction in the sign.

It is this construction of meaning that forms the basis of the formation of ideology in a sign. As one of the studies of thought in cultural studies, semiotics certainly sees how culture is the basis of thought from the formation of meaning in a sign. Semiotics study systems, rules, conventions that allow these signs to have meaning (Kriyantono, 2007: 261).

The figures in semiotic studies are Roland Barthes. Barthes is a figure that is so identical to semiotic studies. Barthes's semiotic thinking can be said to be the most widely used in research. As the successor of Saussure's thought, Roland Barthes emphasizes the interaction between the text with the personal and cultural experiences of its users, the interaction between conventions in the text and conventions experienced and expected by its users (Kriyantono, 2007: 268). Barthes's operational concept of thought is known as the Order of Signification. Put simply, Barthes's semiotic study can be described as follows:

1. Denotation is a real meaning, or a phenomenon that appears with the five senses, or can also be called a basic description.

2. Connotation is a cultural meanings that appear or can also be called meanings that arise because of cultural construction so that there is a shift, but still attached to the symbol or sign.

Two aspects of the study from Barthes above are the main studies in researching about semiotics. Then Barthes also includes aspects of myth, which is where when the connotation aspect becomes popular thought in the community, then myths have been formed on these signs. Barthes thought is considered the most operational so often used in research.

According to Charles Sanders Pierce: Semiotic analysis consists of three important aspects so it is often called a triangle of meaning (Littlejohn, 1998). The three aspects are:

1. Signs, in semiotic studies, signs are the main concept used as material for analysis in which 
signs contain meaning as a form of interpretation of the intended message. Put simply, signs tend to be visual or physical in nature that are captured by humans.

2. Reference to a sign or object, an object is a social context in which its implementation is used as an aspect of meaning or as referenced by the sign.

3. User Sign (interpretant), the concept of thought of people who use the sign and reduce it to a certain meaning or meaning that is in someone's mind about the object to which a sign is referred (Kriyantono, 2007: 263).

\section{Research Methods}

This study uses descriptive qualitative methods that are relevant to the phenomenological methodology that distinguishes it from ordinary qualitative research are:

a. Exploring values in human experience and life.

b. The focus of research is on the whole not on the parts that make up the whole.

c. The aim of the research is to find the meaning and nature of the experience, not just to search for an explanation or to find measurements of reality.

d. Obtain a picture of life from a first-person perspective through formal and informal interviews.

e. The data obtained is the basis for scientific knowledge to understand human behavior.

f. The questions made reflect the interests, involvement and personal commitment of the researcher.

g. Seeing experience and behavior as a unity that cannot be separated between subject and object or between parts of the whole (Creswell, 1998: 86).

The reason for using this research method and technique is because the problem studied concerns the phenomenon and meaning of the monument buiding in the life of Toba Batak tribe in Samosir Regency. Through a phenomenological approach, it is hoped that descriptions of phenomena that appear on the ground can be interpreted, their meanings and contents deeper.

Phenomenological inquiry starts with silence. Silence is an act to uncover the meaning of something being researched. What is emphasized by phenomenologists is the subjective aspect of people's behavior. As an implementation, this method seeks to enter into the conceptual world of the subject being studied by the author so that he understands what and how an understanding is developed by them around events in his daily life. Phenomenologists believe that in living things there are various ways to interpret experiences through interactions with others.

The purpose of descriptive research is to describe and understand the behavior patterns of a society as it is in a wholistic context (Martodirdjo, 1991: 74). Cultural mission and cognition underlying the phenomenon of Toba Batak culture in perceiving and appreciating the monument buiding (Tamba Na Timbo).

The location of this research is Pangururan Subistrict and Palipi Subdistrict, Samosir Regency. The selection of research sites in Samosir Regency is focused on two sub-districts namely Pangururan Subistrict and Palipi Subistrict. The reason for the sampling of places in these two sub-districts, with the consideration that in the two sub-districts there were more monuments built by community figures or clans compared to other sub-districts. 


\section{Discussion}

In general, the monument buiding contained in the life of Toba Batak community in Samosird Regency can be categorized into two types namely the meaning of the monument buiding from the perspective of religion and culture. The two meanings can be described as follows:

\subsection{Meaning of the Monument Buiding in Terms of Religion}

As a religious society, success encourages every human being to give thanks according to his religious beliefs to God Almighty. The beliefs of Batak ancestors' religions that are still strong and have not been eroded from the heart by the church's ministry, make Batak people return to their ancestral religious beliefs that are adapted to the pragmatism of present life.

The construction of the clan monument is carried out by all the descendants of the mother clan wherever they are. For example: the Silalahi clan consists of eight main clans, namely Sihaloho, Situngkir, Sondiraja, Sidabariba, Sidebang, Sinabutar, Pintu Batu and Tambunan. The ancestor of all the clans is Raja Silahi Sabungan. The monument that was built was called the Silahi Sabungan monument (Silalahi monument), in Silalahi village, Silalahi Nabolak area. Ancestor worship monument is built high soaring with a variety of models and ornaments in accordance with the desires of the hearts of each clan. This development was carried out by collecting funds (tumpak) from all clan descendants, through "punguan marga" in various cities and villages, both those in Bona Pasogit, and those in overseas (parserah).

In the monument they prepared a place for the bones (saring-saring) of their ancestors. Before the ancestral bones were removed, they usually used the services of the datu to find the actual location of the grave, so that there was no error in the mangongkal holi event, because the error could cause anger from the "somangot" of the clan ancestors. The grandeur of the monument is a sign of the many blessings or blessings received by the descendants of the clan from the spirits of their ancestors. All the blessings symbolize the greatness and greatness of the spirit, so that it is appropriate for the spirit to be given a place of honor, as an expression of gratitude from all of its descendants (pinomparna).

At the inauguration of the monument, a number of tonggos were offered to Debata Mulajadi Nabolon, in order to bring the ancestral spirits to his torch. As for what was said was as follows:

"Ditonggo asa diparo Mulajadi Nabolon, tondi ni ompu tu tuguna binahen saring-saring ni amanta on tu tambak na guminjang tu ginjang ma parhorasan ba, tu ginjang ma panggabean patumpahon ni ompunta martua debata dohot tumpahon ni tondi ni angka raja di loloan".

Means:

"With the addition of this grandmother's bones, to the graves or monuments which are thought to have increased prosperity, success and prosperity, which is done by the happy Debata, and supported by the spirits of the kings present here".

The meaning of the tambak in Toba Batak community is adjusted to the meaning, function and purpose. From the results of the interview shows that the tambak is created from the results of ideas, ideas contained in their minds, and the results of activities or actions of human works. Therefore, tambak as material culture are the result of ideas, ideas and activities as well as the work of Batak Toba people, having meaning and function that are important in 
the lives of some Toba Bataks, especially in relation to belief systems. Through interpretation of the physical attributes contained in the building of the tambak or monument associated with the belief system, the environment, and the social culture of the community will be revealed symbolic meaning and social function. The meaning and meaning of the monument building to Batak Tobadi community Samosir Regency can be seen in terms of religion are as follows:

\section{a. The Meaning of Sacralization}

The monument built by Toba community, especially in Samosir Regency, is a form that is considered sacred by the surrounding community. Through the monument and simin, all ancestors were respected by their descendants, especially at the time of their lives, their tondi was very well cared for and also after death they were still worshiped by their offspring. As explained by Oktavia Sitohang as follows:

"The form of respect for the ancestors is to form monuments by their descendants to their ancestors. This proves that Toba Batak people highly respect their ancestors".

\section{b. The Meaning of the Position of the Soul}

Through the erection of monuments and excavation of bones and various offerings (food offerings to the spirits of the ancestors), the spirits of Batakakan ancestors are increasingly elevated through these ceremonies. As explained by Tamaisi Boru Sinaga (Ompu Rini Boru Sinaga) as follows:

"With the monuments built by descendants of ancestors who have died, the ancestors have a high position in nature. With these ceremonies, the position of ancestral spirits is getting higher ".

\section{c. The Meaning of the Blessing}

Through a special event for blessing and excavation of the bones of Batak people expect a better life. With this event the descendants of the ancestors who have died will be blessed by the ancestors. As stated by Nelson Situmorang (Ompu Samuel Situmorang) as follows:

"The construction of ponds and monuments for the people of Samosir indirectly we want to obtain and expect our Ompu-Ompu to bless us as their living descendants to always feel happy and peaceful in everyday life"

\section{d. The Meaning of Strengthening Alliance Bonds}

The feast of the monument is also a means of reaffirming the spiritual ties or fellowship between all clan descendants, strengthening the sense of clan solidarity. The meeting between clans in Bona Pasogit is expected to strengthen the ties of relatives who have begun to loose. The party is a place for people who have lived far apart to get to know one another's offspring.

The ties of kinship and sense of clan solidarity in Batak people are known to be very strong and the strength of that bond is seen in the gathering of fellow clans in the overseas area. Since the fifties there has been a significant migration flow from Batak people, who came out of the village of Pasogit. The scattering (parserah) of Batak people to various regions in Indonesia can loosen the bonds of solidarity and a sense of solidarity among fellow clans. 


\subsection{Meaning of the Monument Buiding in Terms of Culture}

The construction of a monument in Batak Toba community of Samosir Regency especially in Pangururan District and Palipi District can be seen from the meaning contained in the symbols and the meaning implicit in each symbol that has been made. The meaning of the construction of a clan in the Samosir Regency is as follows:

\section{a. The Meaning of Unifying Clans}

Supporting the monument buiding is a clan group called saompu, which has a common ancestor but also a small clan. The original ancestors were named ompu parsadaan. This initiative came about because seeing that in the midst of big city society people were no longer distinguished according to ethnicity or according to their lives among the ethnic groups, this gave rise to the need to ensure their own identity. As explained by Timbang Simbolon (Ompu JonokSimbolon) as follows:

"The monument in almost every clan in Samosir Regency is arguably the unifying clan that has been spread all over the world. They will meet each other at large events. Besides, if they are abroad and we are also abroad and meet with people with the same family, they will consider us as their siblings".

\section{b. The Meaning of Conflict Resolution}

The construction of a monument can function as a means of resolving disputes between brothers that occurs within a clan. As happened with the Pandiangan clan, through the construction of this monument, fellow Pandiangan clans will often meet and solve various problems that occur among themselves, as explained by Nermika Pandiangan as follows:

"We, the Pandiangan tribe, have had conflicts. But over time and sit together in deliberation. Every time there is a problem there is a way out and every time we have a conflict, we can definitely solve it. The important thing is we want to deliberate".

\section{c. The Meaning of Raising Social Status}

In the construction of a monument also has a meaning although it is not explicitly stated that the construction of a monument can elevate the social status of a clan among other clans. Clans who have great people or who have good economic capabilities are able to build a monument with luxury. From the construction of the monument, it is implied that the clans who have luxury monuments are those who have great people both who act as the state apparatus and as well-known entrepreneurs. It aims to elevate the social, personal, family status of the village yard. Ability in the field of material that is considered already established, raises sikaptoal (arrogant competition). Among Bataks themselves there is a thought that the success so far has been thanks to the spirits of the ancestors, so that the desire arose to dig up the bones of the ancestors' bones and put them in a monument by holding a festive party.

Exhibition of Social Prestige, hamoraon, hasangapon, and hagabeon (wealth, glory and success) are things that Batak people crave. Obedience in carrying out various traditional ceremonies is the way taken to guarantee the achievement of the intended purpose. By worshiping the spirits of his ancestors, these spirits will bless everything he does. The grandeur of the monument and the amount of the cost of the monument is a means for the clan to show their prowess before other clans. Bataks are very eager to show the greatness of each of their clans.

The grandeur of the monument is a means to show the height of social prestige for other clans. This method was taken as a way to obtain recognition from other clans for the 
greatness or glory of their clans. They are eager to show that many of their clan descendants have very high education, a lot of wealth, high positions, and various other greats. And their success overseas, to relatives of the clan who were in Bona Pasogit. This is as explained by Rusdi Sinaga as follows:

"All the people who are in the area will be invited to participate in every process of the event that will be made by their clans in the monument that has been formed. Through this meeting anyone who has succeeded and has other greats will be introduced. In addition, there are also those who have not succeeded in being able to tell to be helped to find work for one clan".

\section{d. The Meaning as a Regional Ownership Seal}

One meaning of the monument is socially and politically as a notification of the land owner or huta (village). As explained by Burhan Sitohang (Ompu Kepin Sitohang) as follows:

"The existence of a monument from a clan will indicate where the place used to be is the village area of the clan itself. Like us, the Sitohang monument is in the Sitohang Village. So the existence of the monument itself will indicate the place of residence of the Sitohang clan"

\section{e. The Meaning of Clans Identity}

The identification function is very prominent in Batak land especially in Samosir Regency where they carry out obligations as family members and through this they show family identity. This relates to the search for group identity by returning to old cultures and ethnic origins by carrying out the construction of ancestral monuments. Migrant children from Toba Batak built a monument of their ancestors where they sought the source or origin of where they came from to clarify their identity. They rediscover old traditions by using modern facilities. Reuniting broken family relationships and strengthen unity in the family. As stated by Nermika Pandiangan as follows:

"Through the monument buiding will strengthen a clan and family that has begun to spread and begin to do overseas. So that the existence of a traditional ceremony will also unite our clans that have spread throughout the world".

\section{f. The Meaning of Social Prestige Exhibition}

The desire to raise social, personal, family status in the yard, because the ability in the field of material is considered already established. In this case the element of toal (arrogant). Among Bataks themselves there is a thought that the success so far has been thanks to the spirits of the ancestors, so that the desire arose to dig up the bones of the ancestors' bones and put them in a monument by holding a festive party.

As we already know that there are three " $\mathrm{H}$ " in Toba Batak community as follows: 1. Hamoraon (wealth)

Basically, Batak people uphold wealth (Hamoraon). Wealth is seen as a virtue while poverty is considered as an unfortunate fate. Rich (mamora) means having a lot of wealth (godang arta). In ancient times property consisted of: rice fields, livestock, houses and gold. So many parables praise the value of this wealth for Batak people:

Simbora gukguk, sai mamora ma hita luhut! Tangkas ma jabu suhat tangkasan ma jabu bona.

Tangkas ma hita maduma tangkasan ma hita mamora. Tubu dingin-dingin di tonga-tonga ni huta. Saur ma hita madingin tumangkas hita mamora. 
Tonggi ma sibahut tabo ma pora-pora. Gabe ma hita huhut jala sude hita mamora.

Tubu ma tandiang di topi aek sibara-bara. Sai gok ma jolma di ginjang, gok ma pinahan di taumbara.

Tinaba hau sampinur di tombak simarhora-hora. Sai lam matorop ma hamu maribur lam marsangap jala mamora.

Andor ras andor ris andor ni simamora. Sai horas ma hita jala torhis sai rap gabe jala mamora.

\section{Hagabeon (has many offspring)}

The general measure of hagabeon in Batak society is if they have descendants baoa (male) and boru (female) who also later have more offspring with the philosophy of maranak sappulu pitu marboru sappulu onom dan falsafah bittang na rumiris oppu pe so ro, anak pe riris nang boru pe torop. If someone in his life already has grandchildren of sons, grandchildren of daughters, and all his sons and daughters are married and have children, then he is called gabe. His Hagabeon became perfect when he was alive he could still see his great-grandchildren (especially from his granddaughter and grandson). That is the perfect peak of Batak society's hagabeon.

\section{Hasangapon}

As for hasangapon, it is rather difficult to find an equivalent word in Indonesian. Literally, sangap can be interpreted as praiseworthy, or exemplary, honorable, almost flawless. Someone who is considered sangap, means he becomes a perfect person, a human who reaches a high status in life, and no scorn from others. Usually a person becomes sangap, if at some level he also has Hamoraon and has a hagabeon. Therefore, in fact it is very difficult to say someone has reached hasangapon now.

\section{Conclusion}

The general meaning of the monument development process in the lives of Toba Batak people in Samosir Regency can be categorized into two, namely the meaning of the monument buiding in terms of religion and culture. In terms of religion, it consists of (1) The Meaning of Sacralization, namely by applying worship to ancestral spirits for all the blessings they receive. (2) The Meaning of the Position of the Souls where ancestors spirits will increasingly be higher in nature through these ceremonies, (3) The Meaning of the Blessing is to expect to be kept away from disasters, diseases and other dangers and (4) The Meaning of Strengthening of Associations, namely the construction of a clan monument, can unite the entire community of clans that have been scattered throughout the world.

In terms of monument building culture is considered a unifying bond between all descendants of the clan, with the ancestral spirits of clans, namely: (1) The Meaning of Unifying Clans, where through the monument buiding can be assessed that each clan makes the monument to gather together, the bonding of brotherhood in one clans and hereditary groups. This is important because there have been many Toba Batak people who have migrated to other areas both domestically and abroad. Through the construction of this monument, all members of the clan can gather to know each other and interact with one another and find out their lineage lineages. (2) The Meaning of Conflict Resolution. Through the construction of the monument, fellow clans who experience conflict will often meet and resolve various problems that occur between these clans. (3) The Meaning of Raising Social Status. Clans who have great people or who have good economic capacity, are able to build a monument with luxury (4) The Meaning as a Stamps on Regional Ownership. The existence of a monument from a clan will indicate where the place used to be is the village area (lumban) 
of the clan itself (defending the clan territory). (5) The Meanings of Clans Identity. With the construction of an overseas monument, Batak Toba tribe built an ancestral monument where they could find or find out the source or origin of where they came from to clarify their identity, and (6) The Meaning of Social Prestige Exhibition, the desire to elevate social status and status and ability economic, personal and family in the yard, this is because the ability in the field of material that is considered already established. The better the monument is built, the higher the social status of the clan. Magnificent monument means symbolizing many people who have been successful in the clan.

\section{References}

Aditjontro, GJ. 2004. Kisah Daud melawan Goliath Di Pedalaman Tanah Batak. Medan: Bakungsu.

Agger, Ben. 2013. Teori Sosial Kritis, Jakarta: Kreasi Wacana.

Batara Sangti, 1997. Adat dan Budaya Batak. Medan: Monora

Ball, Van. 1976. Sejarah Dan Filsafat Antropologi Jilid I dan II. Jakarta: Gramedia.

Barth, Fredrick, 1986. Kelompok Etnik dan Batasannya, Jakarta: UI-Press.

Campbell, Tom. 1994. Tujuh Teori Sosial, Sketsa, Penilaian, Perbandingan. Yogyakarta. Penerbit Kanisius.

Castles, Lance. 2001. Kehidupan Politik Suatu Kepresidenan di Sumatera: Tapanuli 19151940. Jakarta: Gramedia.

Creswell, J W. 1998. Qualitative Inquiry and Reseasch Design: Choosing Among Five Traditions. USA: Sage Publication

Danim, Sudarwan. 2002. Menjadi Peneliti Kualitatif. Jakarta: Pustaka Setia.

Dede, Mulyanto, 2014. Pemikiran Antropologi. Jakarta: Marjin Kiri.

Durkheim, E. 1964. The Division of Labour in Society, (terjemahan George Simpson), New York: The Free Press.

Evans - Pritarchad, E. E, 1986. Antropologi Sosial (alih bahasa: Nancy Simanjuntak), Surabaya: Bumi Aksara

Furchan. Arief, 1992. Metode Penelitian Kualitatif, Surabaya: Usaha Nasional

Garna, Judistira K. 1992. Teori-Teori Perubahan Sosial, Bandung: PPS - UNPAD

Gerzt, Clifford. 1973. The Interpretation of Cultures. New York: Basic Books

Giddens, A. 1985. Kapitalisme dan Teori Sosial Modern, Jakarta: UI-Press

Gultom, J. 1992, Dalihan Na Tolu Nilai Budaya Suku Batak, Medan: Firma Hasmar.

Hans-dieter, Evers, 1988. Teori Masyarakat Proses Peradaban Dalam Sistem Dunia Modern, Jakarta: Yayasan Obor.

Hartoko. Dick, 1984. Manusia dan Seni. Yogyakarta. Kanisius.

Ihromi, T. O, 1987. Pokok - Pokok Antropologi Budaya, Jakarta: Gramedia.

Ismail, et al. (2019). Social Changes in the Post-Tsunami Banda Aceh City. Budapest International Research and Critics Institute-Journal (BIRCI-Journal); 45-50.

Kartini, 1983. "Asosiasi Klan Orang Batak Toba di Jakarta”. Dalam Prisma No. 1 Tahun XII. Jakarta: LP3ES.

Kuswarno, Engkus, 2009. Metodologi Penelitian Komunikasi, Fenomenologi Konsepsi, Pedoman dan contoh Penelitian. Bandung: Widya Padjdjaran

Lajar, A.B. 2005. "Jaques Derrida dan Perayaan Kemajemukan", dalam Mudji Sutrisno \& Hendar Putranto (ed). Teori-teori kebudayaan. Yogyakarta: Kanisius

Lauer, R. H, 1993. Perspektif Tentang Perubahan Sosial, (terjemahan), Jakarta: Bina Aksara.

Malau Ismail, 1985. Mengenal Batak, Medan: CV. Kiara.

Malinoski, B. 1983. Dinamika Bagi Perubahan Budaya, Kuala Lumpur: Adabsi SDN. BHD.

Murdock, Peter, George. 1949. Social Structure. London: The Free Press.

Nababan, S.A.E. 1994. Mencari Keseimbangan. Jakarta: Sinar Harapan. 
Nainggolan, Togar. 2012. Batak Toba di Jakarta Kontiunitas dan Perubahan Identitas. Medan: Bina Media Perintis.

Ogburn, W. F, 1986. Ketertinggalan Kebudayaan, Jakarta: Rajawali Press.

Pane, I.F. (2020). Architectural Design by Considering Communication Systems with Observer(Case Study: KLIA Internasional Airport). Britain International of Exact Sciences (BIoEx) Journal; 11-18.

Parlindungan, O. M, 2007. Tuanku Rao. Yogyakarta: LKIS.

Pasaribu B. John. 2002. Pengaruh Injil Dalam Adat Batak, Jakarta. Sinar Harapan.

Pritchard, EE. Evans. 1986. Antropologi Social. Jakarta: Bumi Aksara.

Radcliffe - Brown, AR. 1979. Structure and Fungtion Primitive Society. London: Routledge and Kegan Paul.

Reid, Anthony, 2002. Pulau Orang Meninggal, Mengapa Orang Batak Membangun Monument. Medan: Bina Media Perintis.

Schutz, Alfred. 1973. The Phenomenology of the Social World. London: Heineman Education Book.

Taylor, J. Steven. 1975. Introduction to Qualitative Research Methods. London: John Wiley \& Son.

Uli, Kojok. 2009. Surat Batak: Sejarah Perkembangan Tulisan Batak. Jakarta: Gramedia.

Yudosaputro, 1993. Wawasan Seni Budaya. Jakarta: Pusat Perbukuan Depdikbud.

Vera, Nawiroh. 2014. Semiotika dalam Riset Komunikasi. Jakarta: Ghalia Indonesia.

Vergouwen. J.C. 2004. Masyarakat dan Hukum Adat Batak Toba. Yogyakarta: LkiS.

Warneck, 1873. Nacht en Morgen op Sumatra Schetsen en Verbalen, Amsterdam: Hoveker \& Zoon.

Zaprulkhan, 2015. Filsafat Ilmu Sebuah Analisis Kontemporer. Jakarta, Rajawali Press.

Zenkins, Rechard. 2008. Identitas Sosial. Jakarta: Bina Media. 